\title{
HUBUNGAN ANTARA HUKUM DENGAN MORAL DALAM ISLAM
}

\author{
Dudi Badruzaman \\ STAI Sabili Bandung \\ Badruzaman.dudi@yahoo.com \\ DOI: https://doi.org/10.29313/sh.v17i1.4226
}

\begin{abstract}
ABSTRAK
Hukum dan moral memiliki hubungan bagaikan roh dan jasad. Salah satunya menjadi tidak berarti jika mengabaikan yang lainnya. Islam menjadikan hukum sebagai alat untuk menciptakan ketaatan seorang hamba terhadap Khaliknya. Hasil pembahasan bahwa (a) Hukum berarti menolak kedzaliman atau penganiayaan. Secara terminologi hukum adalah suatu aturan dan ukuran perbuatan yang menjuruskan perbuatan- perbuatan tersebut ke tujuan yang semestinya. Kata hukum disandingkan dengan Islam, maka yang dimaksud adalah kitab Allah yang berkaitan dengan perbuatan manusia (mukallaf) baik berupa perintah, larangan, pilihan maupun ketetapan-ketetapan hukum kausalitas. Adapun moral berarti kesusilaan, budi pekerti. Sedang secara istilah, moral diartikan sebagai ajaran tentang baik buruk perbuatan dan kelakuan yang sering pula disamakan dengan etika. Sedangkan dalam Islam moral dipadankan dengan akhlak. (b) Hukum dan moral menurut sebagian pakar hukum adalah terpisah sedangkan sebagian pakar hukum lainnya mengatakan keduanya harus bersatu. (c) Menurut Islam antara hukum dan moral tidak bisa dipisahkan dan harus bersandar pada al-Quran dan hadis sebagai rujukan pertama dan utama dalam menentukan dan menetapkan suatu perkara.
\end{abstract}

Kata Kunci: Hukum, Moral, Maslahat dan Mafsadat.

\section{ABSTRACT}

Law and morals have relationships like spirits and bodies. One of them becomes meaningless if you ignore the others. Islam makes law a tool to create a servant's obedience to the Creator. The results of the discussion are that (a) Law means rejecting tyranny or persecution. In terminology, law is a rule and measure of action that directs these actions to their intended purpose. The word law is juxtaposed with Islam, so what is meant is the book of Allah which is related to human actions (mukallaf) in the form of commands, prohibitions, choices and provisions of the law of causality. The moral means morality, character. While in terms, morals are interpreted as teachings about both bad deeds and behaviors that are often likened to ethics. Whereas in Islam moral is matched with morals. (b) Law and morals according to some legal experts are separate while some other legal experts say they must unite. (c) According to Islam, between law and morals cannot be separated and must rely on the Koran and hadith as the first and foremost reference in determining and determining a cases.

Keywords: Legal, moral, maslahat and mafsadat. 


\section{A. PENDAHULUAN}

\section{Latar Belakang Masalah}

Sejak dahulu baik dalam filsafat maupun ilmu kalam sering diperdebatkan apakah sesuatu yang diperintahkan itu mengandung kebaikan atau karena diperintahkan sesuatu itu lalu menjadi baik begitu pula sebaliknya apakah sesuatu yang dilarang itu karena mengandung keburukan. Perintah dan larangan adalah aturan dalam hukum, sedang kebaikan dan keburukan adalah nilai moral dari suatu perbuatan. Eksistensi sebuah hukum pada dasarnya diwujudkan dalam rangka terciptanya tatanan kehidupan yang aman dan tenteram dalam kehidupan bermasyarakat. Hal itu berlaku juga dalam hukum Islam. Hukum Islam (syari’at Islam) mengandung tujuan untuk mewujudkan kemaslahatan dan kebaikan hidup yang hakiki bagi manusia, baik secara individual maupun sosial. Alquran sendiri sebagai sumber utama hukum.

Islam menyatakan dirinya sebagai petunjuk bagi seluruh manusia, dan memerintahkan kepada manusia untuk taat kepada Allah dan Rasul-Nya dengan menjalankan ajaran-ajaran dan seluruh perintah-Nya. Berdasarkan cakupan tujuan hukum di atas, muatan hukum Islam yang terefleksi dalam fiqh (hukum Islam) memperlihatkan adanya empat pembidangan utama, yakni bidang ibadat, bidang muamalah, bidang munakahat dan bidang jinayat. Hubungan sebagai makhluk dengan Khaliknya (Allah) diatur penataannya melalui hukum ibadat.

Tata hubungan antara manusia dengan sesamanya dalam lalulintas pergaulan dan hubungan sehari-hari untuk pemenuhan kebutuhan hidupnya diatur dalam hukum muamalat. Tata hubungan manusia dalam hubungan berkeluarga dalam lingkungan berumah tangga diatur dalam hukum munakahat sedangkan terakhir tata hubungan keselamatan, keamanan serta kesejahteraannya yang ditegakkan oleh pemegang kekuasaan umum atau badan peradilan diatur melalui hukum jinayat. Adanya hukum ibadat dalam batang tubuh hukum Islam yang bersumber dari Alquran dan hadis itu merupakan ciri utama hukum Islam. Ibadat tidak lain adalah perwujudan dari aqidah yang diimani. Di sinilah terlihat secara nyata keterkaitan hukum ini dengan keimanan. Hubungan antar makhluk (manusia) dengan Khalik (Allah) diatur secara pasti yang biasa dikenal dengan ibadah mahdah. Adanya hukum niat dalam semua jenis ibadah yang diberi peran menentukan nilai perilaku manusia, memperlihatkan dengan jelas 
peran moral dan hukum itu. Di sini tampak pula titik awal perbedaan antara pemahaman hukum menurut ilmu hukum dengan hukum Islam yang bersumber dari Alquran. Menurut ilmu hukum, hukum itu terdiri dari perintah dan larangan serta hak dan kewajiban. Apa yang dimaksud dengan nilai moral atau akhlak tidaklah tergolong hukum. Moral berada pada sisi lain alias di luar hukum. Sedang hukum Islam, penegakan hukum berjalan sekaligus dengan pembinaan moral atau akhlak yang bersumber dari aqidah/keimanan. Adanya dua sudut pandang yang berbeda terhadap hukum dan moral seperti di atas, maka menarik untuk dikaji seperti bagaimana sesungguhnya hukum dan moral itu dalam Islam.

\section{Identifikasi Masalah}

Artikel ini akan membahas tiga topik yang bekaitan dengan hubungan yang muncul mengenai makna hukum dan moral, kemudian hubungan antara hukum, moral dan agama, serta nilai-nilai yang terdapat dalam hukum terhadap dan moralitas dalam pandangan Islam.

\section{Metode Penelitian}

Metode penelitian dalam penulisan ini menggunakan pendekatan yuridis normatif karena penulis melakukan inventarisasi peraturan perundangundangan yang mengatur masalah asuransi. Spesifikasi penelitian menggunakan deskriptif analitis dengan menggambarkan suatu kenyataan dan fakta-fakta yang berkaitan dengan hukum perasuransian. Teknik analisis data menggunakan metode kualitatif karena tidak menggunakan rumus dan angka..

\section{B. PEMBAHASAN}

\section{a. Makna Hukum dan Moral}

Term hukum yang digunakan dalam bahasa Indonesia saat ini berasal dari kata hukum, yang berarti norma atau kaidah, yakni aturan, tolok ukur, patokan, pedoman yang dipergunakan untuk menilai tingkah laku manusia dan benda. ${ }^{1}$ Secara

\footnotetext{
${ }^{1}$ Muhammad Daud Ali, Hukum Islam: Pengantar Ilmu Hukum dan Tata Hukum Islam di Indonesia, RajaGrafindo Persada, Jakarta, 2002, hlm. 39.
} 
etimologis kata hukum bersumber dari kata ha ka ma yang berarti menolak. Terbentuklah kata "al- hakamu" yang berarti menolak kezaliman atau penganiayaan. $^{2}$

Secara terminologi hukum adalah suatu aturan dan ukuran perbuatan yang menjuruskan perbuatan-perbuatan tersebut ke tujuan yang semestinya. Jika kata hukum bila disandingkan dengan Islam, maka yang dimaksud hukum Islam, adalah kitab Allah yang berkaitan dengan perbuatan manusia (mukallaf), baik berupa perintah, larangan, pilihan maupun ketetapan-ketetapan hukum kausalitas. ${ }^{3}$

Secara etimologis moral berasal dari Bahasa Belanda moural, yang berarti kesusilaan, budi pekerti. Sedangkan menurut W.J.S. Poerwadarminta moral berarti ajaran tentang baik buruk perbuatan dan kelakuan. Dalam Islam moral dikenal dengan istilah akhlak. al-Ghazali dalam Ihya' Ulumuddin menerangkan tentang definisi akhlak sebagai berikut:

Akhlak adalah perilaku jiwa, yang dapat dengan mudah melahirkan perbuatan- perbuatan, tanpa memerlukan pemikiran dan pertimbangan. Apabila perilaku tersebut mengeluarkan beberapa perbuatan baik dan terpuji, baik menurut akal maupun tuntunan agama, perilaku tersebut dinamakan akhlak yang baik. Apabila perbuatan yang dikeluarkan itu jelek, maka perilaku tersebut dinamakan akhlak yang jelek. Adapun moral secara etimologis berasal dari bahasa Belanda moural, yang berarti kesusilaan, budi pekerti. Sedang secara istilah, moral diartikan sebagai ajaran tentang baik buruk perbuatan dan kelakuan. Dari segi makna kata ini sering pula disamakan dengan etika walau secara pengertian berbeda. Hal senada juga dikemukakan oleh Hasanuddin Sinaga, bahwa etika dan moral memang memiliki kesamaan, namun ada pula perbedaannya, yakni etika lebih banyak bersifat teori, sedangkan moral lebih banyak bersifat praktis. Etika memandang tingkah laku perbuatan manusia secara universal (umum), sedangkan moral secara lokal. Moral menyatakan ukuran, etika menjelaskan ukuran itu.

Dalam beberapa hal antara etika dan moral memiliki perbedaan. Pertama, kalau dalam pembicaraan etika, untuk menentukan nilai baik atau buruk perbuatan

${ }^{2}$ Abi al-Husain Ahmad bin Faris bin Zakariya, Mu'jam Muqayis al-Lughah, Juz II, Dar al-Fikr, 1979, Beirut, hlm. 91.

${ }^{3}$ Abdul Wahab Khallaf, Op. Cit., hlm. 174. 
manusia menggunakan tolok ukur akal pikiran atau rasio, sedangkan dalam pembicaraan moral, tolok ukur yang digunakan adalah norma-norma yang tumbuh dan berkembang dan berlangsung di masyarakat. Asumsi moralitas Immanuel Kant sebagai sebuah parameter tindakan bahwa manusia dalam berbuat pada intinya hanya terikat dua hal, yaitu tindakan yang sesuai dengan kewajiban (moral) dan tindakan yang dilakukan demi kewajiban.

Pandangan seperti ini dikemukakan Franz Magnis Suseno bahwa Etika adalah pemikiran kritis dan mendasar tentang ajaran-ajaran dan pandanganpandangan moral, sedang ajaran-ajaran moral adalah ajaran-ajaran, ketentuanketentuan, petunjuk- petunjuk dan ketetapan-ketetapan tentang bagaimana manusia mesti hidup menjadi manusia yang baik. Dengan demikian, apabila ajaran-ajaran moral mengandung perintah untuk mengikuti dan melaksanakan ajaran-ajaran tertentu, maka etika hendak memahami mengapa manusia mesti mengikuti ajaranajaran yang diperintahkan untuk diikuti itu. Karena itu, etika dapat dipandang mengandung kekurangan karena tidak berwenang memerintah. Namun sekaligus mengandung kelebihan karena etika menjadikan manusia memahami mengapa ia mesti mengikuti perintah ajaran-ajaran tertentu. Dalam Islam moral dipadankan dengan akhlak, sebagaimana yang terungkap dalam Ihya Ulumuddin yang mendefinisikan akhlak sebagai perilaku jiwa yang dapat dengan mudah melahirkan perbuatan-perbuatan, tanpa memerlukan pemikiran dan pertimbangan.

Apabila perilaku tersebut mengeluarkan beberapa perbuatan baik dan terpuji, baik menurut akal atau agama, perilaku tersebut dinamakan akhlak yang baik. Apabila perbuatan yang dikeluarkan itu jelek, maka perilaku tersebut dinamakan akhlak yang jelek. Untuk mengetahui perbuatan baik dan terpuji, dalam buku Falsafah Akhlak, Murtadha Mutahhari membagi perbuatan manusia menjadi dua yaitu perbuatan alami dan perbuatan akhlaki. ${ }^{4}$

Menurutnya perbuatan alami tidak menjadikan pelakunya layak puji, seperti makan bila lapar, membela diri bila dihina. Sedang berterima kasih atau memberi

\footnotetext{
${ }^{4}$ Murtadha Mutahhari, Falsafah Akhlak Kritik atas Konsep Moralitas Barat, diterjemahkan oleh Faruq bin Dhiya', Pustaka Hidayah, Bandung, 2000, hlm. 29.
} 
hadiah adalah contoh perbuatan akhlaki sehingga pelakunya layak dipuji. Intinya perbuatan akhlaki itu ialah segenap khidmat yang dilakukan oleh seseorang untuk orang lain, tanpa mengharapkan sesuatu selain berbuat baik kepada orang tersebut. Standar atau ukuran baik dan buruk atau bagus dan jelek suatu perbuatan tentu berbeda bagi setiap individu dalam memaknainya akibat beda waktu dan tempat.

Perbedaan itu jika terjadi terletak pada bentuk, penerapan atau pengertian yang tidak sempurna terhadap konsep moral yang disebut ma'ruf dalam bahasa AlQur'an. Meskipun demikian, setiap orang dan masyarakat tentu memiliki standar umum yang disepakati untuk menentukan aturan yang harus dijalani. Ukuran umum itu mungkin saja berbeda dari satu masyarakat dengan masyarakat lainnya, tapi ada hal-hal pokok tertentu ada persamaannya antara semua manusia dalam menilai baik dan buruk. ${ }^{5}$ Misalnya, kerendahan hati, kesederhanaan, keadilan, kasih sayang, kedzaliman, kebohongan, mungkin terjadi perbedaan kecil dalam pelaksanaan nilainilai itu dalam kehidupan sehari-hari.

\section{b. Sanksi Hukum Pihak Penanggung Atas Penolakan Klaim Asuransi Dari Pihak Tertanggung Berdasarkan Hukum Positif}

Ada sisi pandangan yang berbeda antara kehidupan masyarakat yang sederhana dengan masyarakat yang memiliki taraf kehidupan yang telah maju dalam menempatkan konsep moral. Pada masyarakat yang masih sederhana, norma susila atau moral telah memadai untuk menciptakan ketertiban dan mengarahkan tingkah laku anggota masyarakat, dan menegakkan kesejahteraan dalam masyarakat. Kesusilaan memberikan peraturan-peraturan kepada seseorang supaya menjadi manusia yang sempurna.

Hasil dari perintah dan larangan yang timbul dari norma kesusilaan itu bersandarkan kepada kebebasan pribadi seseorang. Hati nuraninya akan menyatakan perbuatan mana yang baik atau buruk dan menentukannya untuk dilakukan atau tidak. Akan tetapi masyarakat yang sudah maju kaidah adat tersebut tidak lagi mencukupi. Hal ini dilatarbelakangi karena persandaran moral adalah kebebasan

${ }^{5}$ Hazairin, Tujuh Serangkai Tentang Hukum, Tintamasa, Jakarta, 1974, hlm. 80-81. 
pribadi. Semakin besar wilayah kebebasan semakin besar pula pertanggungjawaban moralnya, demikian menurut Komaruddin Hidayat. Lanjutnya, dalam perspektif ini, paham Jabariah tidak ada tempat dalam konsep apa yang disebutnya dengan etika voluntarisme rasional Kontianisme. Dalam tindakan manusia baik cara berfikirnya maupun sifatnya tidaklah sama, sehingga dalam implementasinyapun banyak sekali usaha yang baik mendapat tantangan dan hambatan. Untuk menghindari cara pandang yang liar diperlukan aturan lain yang tidak disandarkan pada kebebasan pribadi tetapi juga mengekangnya dalam bentuk paksaan dan sanksi. Inilah yang disebut dengan hukum. ${ }^{6}$

Jika dalam kesusilaan yang dimuat adalah anjuran yang berupa pujian dan celaan, dalam kaidah hukum yang dimuat adalah perintah dan larangan yang diperkuat dengan ancaman, paksaan dan sanksi bagi orang yang mengabaikannya, meski coraknya berbeda, maupun bentuk-bentuk yang dilarang dalam hukum adalah bentuk-bentuk yang dipuji dan dicela dalam kesusilaan sehingga hakikatnya patokan hukum tersebut berurat pada kesusilaan. ${ }^{7}$

Unsur ancaman dan paksaan dalam hukum merupakan sebuah keharusan. Sebab tanpa adanya unsur ini hukum akan menjadi mandul, alias tidak bermakna dan bahkan cenderung tidak ada gunanya. Oleh karena itu masing-masing kelompok atau masyarakat akan memberikan suatu bentuk atau berbagai kemungkinan bentuk unsur tersebut. Masyarakat yang satu akan memberi bentuk yang berbeda dengan masyarakat yang lain. Dengan demikian, setiap tatanan sosial akan memberi caracara dan jalannya sendiri yang cocok untuk memaksa anggota-anggota masyarakat berbuat seperti yang dikehendakinya. ${ }^{8}$

Hazairin menyatakan bahwa hukum tanpa moral adalah kezaliman. Moral tanpa hukum adalah anarki dan utopia yang menjurus kepada peri kebinatangan. Hanya hukum yang dipeluk oleh kesusilaan dan berakar pada kesusilaan yang dapat mendirikan kemanusiaan. Lebih lanjut Dr. M. Muslehuddin menerangkan bahwa

\footnotetext{
${ }^{6}$ Satjipto Raharjo, Ilmu Hukum, Citra Aditya Bakti, Bandung, 1991, hlm. 27-28.

${ }^{7}$ Hazairin, op.cit., hlm. 85.

${ }^{8}$ M. Maslehuddin, Philosophy of Islamic law and The Orientalists, Islamic Publication Ltd., Lahore, 1987, hlm. 278.
} 
hukum tanpa keadilan da moralitas bukanlah hukum dan tidak bisa bertahan lama. Sistem hukum yang tidak memiliki akar substansial pada keadilan dan moralitas pada akhirnya akan terpental. ${ }^{9}$

Hukum positif yang didukung oleh Coulson dan Kerr dipisahkan dari keadilan dan etika. Menurut hukum murni ala Kelsen, etika dan filsafat sosial jauh dari hukum. Ia menentang filsafat dan berkeinginan untuk menciptakan ilmu hukum murni, meninggalkan semua materi yang tidak relevan, dan memisahkan yurisprudensi dari ilmu-ilmu sosial. ${ }^{10}$ Timbul pertanyaan apakah hukum itu bersatu dengan moral atau justru terpisah dan berdiri sendiri. Para pakar hukum berbeda dalam menanggapi hal ini. Hazairin dalam bukunya Demokrasi Pancasila sebagaimana yang dikutip Fathurachman Djamil ${ }^{11}$ menyatakan, bahwa hukum tanpa moral adalah kezaliman, sedang moral tanpa hukum adalah anarki dan utopia yang menjurus kepada peri-kebinatangan. Hanya hukum yang dipeluk oleh kesusilaan dan berakar pada kesusilaan yang dapat mendirikan kemanusiaan. Lebih lanjut, M. Maslehuddin menerangkan bahwa hukum tanpa keadilan dan moralitas bukanlah hukum dan tidak bisa bertahan lama. Sistem hukum yang tidak memiliki akar substansial pada keadilan moralitas pada akhirnya akan terpental.

Selain tokoh-tokoh Islam di atas tokoh filsafat Barat juga seperti Kant dan Friedmann menurut M. Maslehuddin juga berpandangan sama bahwa hukum yang dipisahkan dari keadilan dan moralitas bukanlah hukum. Dalam suatu masyarakat ada hubungan erat antara moralitas sosial dan perintah hukum. pengaruh moralitas sosial atas perintah hukum pada umumnya tergantung pada karakter masyarakat. Masyarakat yang liberal dan plural akan lebih mudah merefleksikan berbagai nilai etika daripada masyarakat otoriter.

Dalam masyarakat yang terikat dengan kebiasaan, ada transformasi berangsur- angsur tingkah laku sosial menjadi kebiasaan hukum dan dari kebiasaan menjadi rumusan legislatif. Sementara pendapat yang menyatakan hukum itu terpisah dengan moral adalah sebagaimana yang dinyatakan oleh Hans Kelsen.

\footnotetext{
${ }^{9}$ Ibid, hlm. 270.

${ }^{10}$ D.F. Schelten, Pengantar Filsafat Hukum, Pent. Bakri Siregar, Erlangga, Jakarta, 1984, hlm. 2223

${ }^{11}$ Fathurachman Djamil, Filsafat Hukum Islam, Logos wacana Ilmu, Jakarta, 1997, hlm. 151. 
Menurutnya hukum itu harus dibersihkan dari anasir-anasir yang tidak yuridis, etis, sosiologis, politis dan sebagainya. ${ }^{12}$ John Austindalam pokok-pokok ajarannya yang memisahkan secara tegas antara moral di satu pihak dan hukum di lain pihak. Dengan menempatkan penilaian baik dan buruk berada di luar bidang hukum.

Aliran imperatif Austinmenganggap hukum sebagai perintah penguasa. Menurut hukum positif, suatu aturan umum tentang tingkah laku yang ditentukan oleh petinggi politik untuk kelompok yang terendah. Tujuan Austinadalah untuk memisahkan secara kejam hukum positif dari aturan-aturan sosial semisal kebiasaan dan moralitas, penekanannya terletak pada perintah mencapai tujuan ini. Konsep perintah secara tidak langsung menyatakan ancaman bagi pelaksanaan sanksi jika perintah itu tidak dipatuhi. Dengan demikian dapat dinyatakan bahwa hukum menjelaskan keharusan (oughtness). Tanpa hukum seseorang hanya memiliki suatu hubungan antara jalan ke tujuan yang oleh Kant disebut imperative hipotesis. ${ }^{13}$ Kalau seseorang ingin bermoral, maka dia dapat menggunakan norma moralitas untuk mencapai keinginan tersebut. Terdapat hukum yang membebankan suatu keharusan mutlak, suatu imperative kategoris; seseorang harus bermoral, senang atau tidak senang maka dia harus menyesuaikan perbuatan-perbuatan anda dengan norma moralitas.

Hukum dan moral harus berdampingan, karena moral adalah pokok hukum, tidak pernah ada pemisahan total hukum dari moralitas, demikian pendapat Friedmann sebagai dikutip oleh Poespoprodjo. Dari beberapa pandangan di atas, penulis lebih cenderung pada pendapat yang mengakui adanya hubungan simbiotik antara hukum dan moral. Bagaikan roh dan jasad, di mana antara keduanya saling membutuhkan untuk memberi makna dalam kehidupan di dunia.

\section{c. Hukum dan Moralitas Dalam Pandangan Islam}

\footnotetext{
${ }^{12}$ Lili Rasyidi dan Ira Thania Rasyidi, Dasar-Dasar Filsafat dan Teori Hukum, Citra Aditya Bakti, Bandung, 2007, hlm. 60.

13 W. Poespoprodjo, Filsafat Moral: Kesusilaan dalam Teori dan Praktek, Pustaka Grafika, Bandung, 1999, hlm. 26.
} 
Hukum Islam adalah seperangkat peraturan berdasarkan wahyu Allah dan Sunnah Rasul tentang tingkah laku manusia mukallaf yang diakui dan diyakini berlaku dan mengikat untuk semua umat yang beragama Islam. ${ }^{14}$ Islam berbeda dari agama- agama lain, karena Islam tidak mengkhotbahkan spiritualitas yang mandul. Dalam Islam hukum dan agama, hukum dan moral tidak bisa dipisahkan satu sama lain. Berdasarkan fungsi utama hukum Islam mengklasifikasikan tindakan yang berkenaan dengan standar mutlak baik dan buruk yang tidak dapat ditentukan secara rasional, karena Allah sendirilah yang mengetahui apa yang benar-benar baik dan buruk.

Dalam masyarakat Islam hukum bukan hanya faktor utama tetapi juga faktor pokok yang memberikannya bentuk. Masyarakat Islam secara ideal harus sesuai dengan kitab hukum sehingga tidak ada perubahan sosial yang mengacaukan atau menimbulkan karakter tak bermoral dalam masyarakat. Hukum Islam harus berjalan sesuai dengan prinsip-prinsip moralitas seperti yang dinyatakan oleh Islam. Hukum Islam memberikan ketentuan bahwa kaidah kesusilaan tidak boleh bertentangan dengan syarat-syarat yang termaktub dalam Al-Qur'an dan Sunnah.

Agama bisa dipahami sebagai hal yang hanya membicarakan masalahmasalah spiritual. Lantaran pemahaman itu, antara agama dan hukum sering dianggap tidak sejalan. Hukum ada untuk memenuhi kebutuhan sosial dan karenanya mengabdi kepada masyarakat. Sedang agama adalah untuk mengontrol masyarakat dan mengekangnya agar tidak menyimpang dari jalurnya yaitu normanorma etika yang ditentukan oleh agamanya sendiri. Agama menekankan moralitas, perbedaan antara benar dan salah, baik dan buruk.

Hukum duniawi memfokuskan diri kepada kesejahteraan sosial dan kurang memperhatikan etika. Hal ini dapat dilihat adanya beberapa pendapat para filosof dan moralis Barat dalam meletakkan ukuran value (nilai) bagi maslahah yang hendak diperoleh manusia dengan kemampuan nalar akal dalam memahami realitas kehidupan. Misalnya aliran hedonisme mengatakan bahwa kesenangan

14 Amir Syarifuddin, Pengertian dan Sumber Hukum Islam (dalam falsafah hukum islam), Departemen Agama dan Bumi Aksara, Jakarta, 1992, hlm.15. 
(kenikmatan) adalah tujuan hidup yang terbaik dan tertinggi. ${ }^{15}$ Muncul aliran utilitarianisme yang berpandangan bahwa kebahagiaan yang besar diperoleh dari jumlah yang besar pula. Semakin seseorang mampu memproduksi kesenangan dan menekan kenistaan berarti ia akan lebih banyak mendapatkan kebahagiaan. Standar pencapaiannya adalah tidak lain adalah individualisme. Artinya bila masing-masing diri mampu memproduksi kebahagiaan sebanyak mungkin secara bebas dan tanpa batas, maka kepentingan kolektif akan terakomodasi dengan sendirinya. ${ }^{16}$

Dalam Islam tolok ukur manfaat atau mudarat, kebaikan atau keburukan sebagaimana diungkap oleh al-Ghazali tidak dapat dikembalikan pada penilaian manusia karena rentan akan pengaruh dorongan nafsu insaniyah namun harus merujuk pada kehendak syara' (Maqashid as-Syari'), yang pada intinya terangkum pada apa yang disebut dengan al-Mabadi'u al-Khamsah. ${ }^{17}$ Jadi kemaslahatan yang dicapai tidak boleh bertentangan dengan universalitas nilai yang dikandungnya walaupun menurut akal manusia hal itu dianggap baik. Sebab terkadang apa yang tampak baik menurut akal sebenarnya tidaklah membawa kebaikan bagi kehidupan manusia itu sendiri dan begitu pula sebaliknya apa yang tampak jelek justru membawa manfaat besar.

Kedua contoh ayat di atas tentu berbeda kadar kebaikan atau keburukan dalam perspektif manusia. Semua orang bisa dikatakan membenci adanya perang apalagi melakukannya, sedang berzina dapat dipastikan semua orang suka melakukannya. Namun untuk keberlangsungan eksistensi kehidupan seluruh makhluk, Allah sudah menetapkan dalam bentuk perintah dan larangan yang termuat dalam al-Quran sunnah rasul-Nya. Dari kedua Kitab ini bersumber nilainilai moralitas yang dibawa oleh Islam, sebagai pembersih bagi jiwa, yang dengannya manusia dapat disebut manusia dan membedakannya dari hewan yang tidak mengenal apa-apa kecuali hanya seruan instink. Moralitas adalah tujuan atau

\footnotetext{
${ }^{15}$ W. Poespoprodjo, op.cit. hlm. 60.

${ }^{16} \mathrm{Ibid}$, hlm. 61. Lihat juga: Abu Yasid, Nalar dan Wahyu Interrelasi dalam Proses Pembentukan Syariat, Erlangga, Jakarta, 2007, hlm. 134.

${ }^{17}$ Lima hal yang harus dipelihara yakni: agama, jiwa, akal, keturunan dan harta. Lihat al-Ghazali, al- Mustashfa min Ilm al-Ushul, Juz I, Dar al-Fikr, Beirut t.t, hlm. 286.
} 
buah di balik penegakan ibadah yang diperintahkan oleh Allah Swt. Shalat misalnya, tujuannya adalah mencegah perbuatan keji dan munkar, zakat adalah untuk membersihkan jiwa dan banyak lagi contoh lainnya. ${ }^{18}$

Tentu saja apa yang dinilai Allah Swt. baik pasti esensinya baik, karena itu diperintahkan dan begitu juga sebaliknya apa yang dinilai-Nya jelek pasti jelek esensinya karena itu dilarang mengerjakannya. Dari uraian di atas dapat dikemukakan, bahwa hukum Islam dalam pelaksanaannya sangat memperhatikan nilai akhlak (moral) dalam seluruh aspeknya yang merupakan akibat dari karakteristik rabbaniyah.

Oleh karena itu, hukum Islam sama sekali dan selamanya tidak mengakui pemisahan peraturan perundang-undangan dari moralitas. Contoh di atas mempertegas pernyataan ini. Adapun kemampuan manusia dalam menilai atau mengetahui baik dan buruk, telah banyak diperdebatkan di kalangan para ahli ilmu kalam dan hasil pemikiran mereka berpengaruh besar terhadap konsep maslahat yang dirumuskan ahli ushul fiqh dalam menentukan tujuan hukum Islam.

Menurut ahli ushul fiqh dari kalangan Asy'ariyah pada umumnya jika dalil naqli bertentangan dengan pemahaman akal dalam masalah syariah maka dalil naqli harus didahulukan, artinya akal tunduk kepada wahyu. Sebab menurut kelompok ini akal manusia tidak dapat menetapkan baik atau buruknya suatu perbuatan. Sedang kebaikan atau keburukan itu hanya ditentukan oleh Allah. Karena itu dalam pandangan mereka akal tidak mengetahui sesuatu itu baik atau buruk, maslahat atau mafsadat. Namun demikian, di kalangan penganut Asy'ariyah sendiri, dalam hal tertentu ada yang berbeda dengan imam mazhabnya.

Dalam kaitan ini al-Juwaini berpendapat, bahwa kebaikan (al-husn) bukan merupakan sifat tambahan dari syariat dan tidak pula dapat diketahui akal, ia hanyalah ungkapan yang ada pada syariat untuk menyatakan pujian bagi pelakunya. Begitu pula halnya keburukan. Menurut al-Juwaini, jika kita memberi sifat tertentu pada suatu perbuatan dengan wajib dan haram, maka tidak berarti kita dapat menetapkan baik buruknya hal itu dengan akal. Maksudnya bahwa

${ }^{18}$ Lihat Yusuf Qardhawi, Legalitas Politik Dinamika Perspektif Nash dan Syariah, Pustaka Setia, 2008, Bandung, hlm. 489. 
perbuatan yang telah ditetapkan perintahnya oleh syara' dimasukkan kategori wajib sedangkan perbuatan yang ditetapkan larangannya oleh syara' disebut haram. ${ }^{19}$ Namun demikian, al-Juwaini sendiri tidak mengingkari, bahwa akal dapat menetapkan tindakan untuk menjauhi yang berbahaya dan melakukan yang bermanfaat. Hal ini menurutnya berlaku dalam masalah-masalah muamalah. Alasannya adalah bahwa apa dianggap baik atau buruk dalam hukum Allah pada dasarnya dapat diketahui mudharat atau manfaatnya, hanya saja Allah tidak akan terpengaruh dengan manfaat atau mudharat bagi manusia itu.

Tampaknya al-Juwaini lebih sejalan dengan teori al-Maturidiyah yang melihat baik dan buruk merupakan dua esensi yang dapat ditetapkan oleh akal. Hanya saja taklif dan hukum tidak dapat ditetapkan semata-semata oleh akal. Pendapat al-Juwaini itu diikuti oleh Izzudin Abdussalam dan Ibn Taimiyah serta Ibn Qayyim, ketiganya penganut faham Asy'ari. Menurut Abdul al-Salam, bahwa kebanyakan kemaslahatan duniawi dan kemafsadatannya dapat diketahui oleh akal. Baginya, orang berakal wajib mendapatkan sesuatu yang maslahat dan meninggalkan sesuatu yang mafsadat sebelum datangnya syariat.

Ibnu Taimiyah, seorang pengikut Hanbali berpendapat bahwa keburukan (al-fahsya) yang dilarang oleh al-Quran pada hakikatnya merupakan perbuatan yang buruk dari segi esensinya. Kemudian muridnya, Ibn Qayyim mengembangkan konsep ini dengan berpendapat bahwa sesuatu yang halal pasti baik sebelum ditetapkan kehalalannya, begitu pula sesuatu yang buruk (alKhabais) adalah buruk sebelum diharamkan oleh wahyu. Berbeda dengan Asy'ariyah, Mu'tazilah berpendapat bahwa baik dan buruk adalah dua esensi yang ditetapkan oleh akal. Artinya akal dapat mengetahui maslahat atau mafsadat dan bahkan dapat menetapkannya.

Tampaknya pernyataan mereka itu terbatas pada sesuatu perbuatan yang kebaikan atau keburukannya dapat ditetapkan oleh akal. Namun anggapan seperti ini tampaknya kurang tepat, sebab menurut Hilli, bagi golongan Imamiyah dan Mu'tazilah, akal dapat mengetahui sebahagian yang baik dan sebagian yang

19 al-Juwaini, al- Burhan fi Ushul al-Fiqh, Juz.I, Dar al-Anshar, Kairo, t.t., hlm. 243. 
buruk. $^{20}$

Abdul Jabbar juga berpendapat demikian, bahwa akal hanya dapat mengetahui kewajiban-kewajiban dalam garis besarnya tapi tidak sanggup merincinya. Untuk menjelaskannya lebih rinci diperlukan wahyu. Oleh karena itu menurutnya perbuatan itu dibagi ke dalam manaqir aqliah yakni perbuatan-perbuatan yang dicela akal seperti bersikap tidak adil dan berdusta, dan munaqir syariah yakni perbuatan yang dicela syariat dan wahyu, seperti mencuri, berzina dan minuman keras. Jadi, rasionalitas yang dibangun paham ini sesungguhnya memiliki aspek persamaan dengan pandangan moralis Barat dan dunia filsafat hukum. Mereka beranggapan bahwa tolok ukur manfaat atau kebaikan atau mafsadat atau kejelekan adalah jumlah kadar yang mampu diserap oleh setiap individu sehingga memiliki dampak kebaikan pula terhadap kebaikan seluruh komunitas.

Dengan demikian, dasar pemikiran mazhab ini adalah kemampuan akal dan bukan pretensi syara' untuk menilainya. Sedang syara' hanya sebagai konfirmasi untuk menjustifikasi terhadap apa yang sudah diakses oleh nalar manusia. Oleh karenanya tidak ada alasan bagi manusia untuk tidak melaksanakan perbuatan yang baik walaupun syariat belum datang. Wallahu a'lam.

\section{PENUTUP}

Hukum berarti menolak kedzaliman atau penganiayaan. Secara terminologi hukum adalah suatu aturan dan ukuran perbuatan yang menjuruskan perbuatanperbuatan tersebut ke tujuan yang semestinya. Kata hukum disandingkan dengan Islam, maka yang dimaksud adalah kitab Allah yang berkaitan dengan perbuatan manusia (mukallaf) baik berupa perintah, larangan, pilihan maupun ketetapan-ketetapan hukum kausalitas. Adapun moral berarti kesusilaan, budi pekerti, sedangkan secara istilah, moral diartikan sebagai ajaran tentang baik buruk perbuatan dan kelakuan yang sering pula disamakan dengan etika, dalam Islam moral dipadankan dengan akhlak.

\footnotetext{
${ }^{20}$ Harun Nasution, Teologi Islam; Aliran-Aliran sejarah Analisa Perbandingan (Cet. Kelima;
} Jakarta: UI-Press, 1989), hlm. 97. 
Hukum dan moral menurut sebagian pakar hukum adalah terpisah sedangkan sebagian pakar hukum lainnya mengatakan keduanya harus bersatu.

Menurut Islam antara hukum dan moral tidak bisa dipisahkan dan harus bersandar pada al-Quran dan hadis sebagai rujukan pertama dan utama dalam menentukan dan menetapkan suatu perkara.

Adapun Dalam Islam hukum dan moral tidak dapat dipisahkan dan merujuk pada satu sumber yang hakiki yaitu Al-Qur'an yang menjadi pedoman hidup bagi manusia. Oleh karena itu, seorang muslim dalam menjalankan hukum harus diimbangi dengan moral dan akhlak yang mulia untuk mengharap keridhaan Allah SWT.

Dalam menjalankan kehidupan sehari-hari seorang muslim sebaiknya bersandar pada hukum Allah SWT yang tertuang dalam Al-Qur'an dan Sunnah Rasulullah SAW, dan senantiasa mengedepankan moral dan akhlak untuk menyayangi sesama manusia. 


\section{DAFTAR ISI}

\section{A. Buku}

M. Amin Abdullah,. The Idea of Universality of Ethical Norms in Ghazali dan Kant. Diterjemahkan oleh Hamzah. Antara Ghazali dan Kant: Filsafat Etika Islam, Bandung: Mizan, 2005.

Muhammad Daud Ali, Hukum Islam: Pengantar Ilmu Hukum dan Tata Hukum Islam di Indonesia, Grafindo Persada, Jakarta, 2002.

Teungku Hasbi Ash-Shiddieqy, Filsafat Hukum Islam. Pustaka Riski Putra, Semarang, 2001.

Fathurachman Djamil, Filsafat Hukum Islam, Logos Wacana Ilmu, Jakarta, 1997.

al-Ghazali. Ihya Ulumuddin, Jilid III, Dar Ihya al-Kutub al- Arabiyah, t.tt.

Hazairin. Tujuh Serangkai Tentang Hukum, Tintamasa, Jakarta, 1974.

al-Juwaini. Al-Burhan fi Ushul al-Fiqh, Juz I, Dar al-Anshar, Kairo, t.t.

C.S.T. Kansil, Pengantar Ilmu Hukum, Jilid I, Cet. IX; Jakarta: Balai Pustaka, 1992.

Nurcholis Madjid, Islam Doktrin dan Peradaban: Sebuah Telaah Kritis tentang Masalah Keimanan, Kemanusiaan, dan Kemodernan, Wakaf Paramadina, Jakarta, 1992.

Ahmad Mansur Noor, Peranan Moral dalam Pembinaan Kesadaran Hukum, Departemen Agama Republik Indonesia, Jakarta, 1985.

Murtadha Mutahhari, Falsafah Akhlak Kritik atas Konsep Moralitas Barat (terj. Faruq bin Dhiya'), Pustaka Hidayah, Bandung, 2000. 